\title{
A hand and honour
}

Keeping pace with the human race.

\section{Brenda Cooper}

John Justice stretched up, fingers scraping at cool morning air, then bent down, cupping his calves, the nanskin registering his fingertips as data points: pressure, heat, sweat, angle.

The hum of the crowd, the band's drums and wind instruments, and even the race announcer seemed far, far away. He already knew what medals felt like. Before his turn in the never-ending war, his men's relay team won gold in London.

Last month, he'd killed the world record for the 10,000-metre run, coming in at just over 24 minutes. No medal for that. Twenty or so news stories, a political cartoon or two, and a combination of joy and bitterness sticking so deep in his gut he threw up all over the course when he was done.

Today, his race would be one-on-one against the man whose record still stood even after John beat it. Hsui Smith, an improbably tall Chinese-American who held the world record in the 10,000 metres. Who would still hold the official record, even after today.

Discrimination was a bitch. Change was tested for like steroids.

John nearly jumped as his coach, Nicolai, placed his metal hand on the small of his back. "Don't think about it. Just run. Run for all of us."

It was nearly time. "I'll win," he nodded at Nicolai, forcing a smile, staring into the shorter, blockier man's deep brown eyes. Nic's naked hope made him clap the man on the back. "I know it matters."

Nicolai headed for the finish line. As the noise and movement swallowed Nic, John muttered, “Damned exhibition.” He had always yearned to be the fastest man in the world. The best that war-woundedJohn could become for child-John was the fastest un-man.

Kim Moon waited for him on the way to the starting blocks, looking more like a debutante than an engineer-medic, her figure slim and curvy in a one-piece shorts outfit. She reached up and hugged him. "Good luck."

He didn't have to fake a smile for her. "It's all your fault."

“They're your legs," she retorted. "The best I've ever made."

One of her customers had new hands and feet with built in temperature controls, and had climbed Everest and K2. After an artificial hand replaced one eaten by frostbite, the climber had made news by chopping off the functioning hand for another of Kim's sculptures.

Without Kim, he would have walked, and run, but never raced. She was all the magic of maths and engineering held together with heart. He leaned down and kissed her forehead, savouring her honeysuckle scent.

As John approached the starting blocks, Hsui stood up from a hamstring stretch and extended a hand. John took it. Where he'd expected to see challenge in the notoriously cocky runner's eyes, he swore he saw fear. His nerves screamed at it. "Why did you agree to this?"

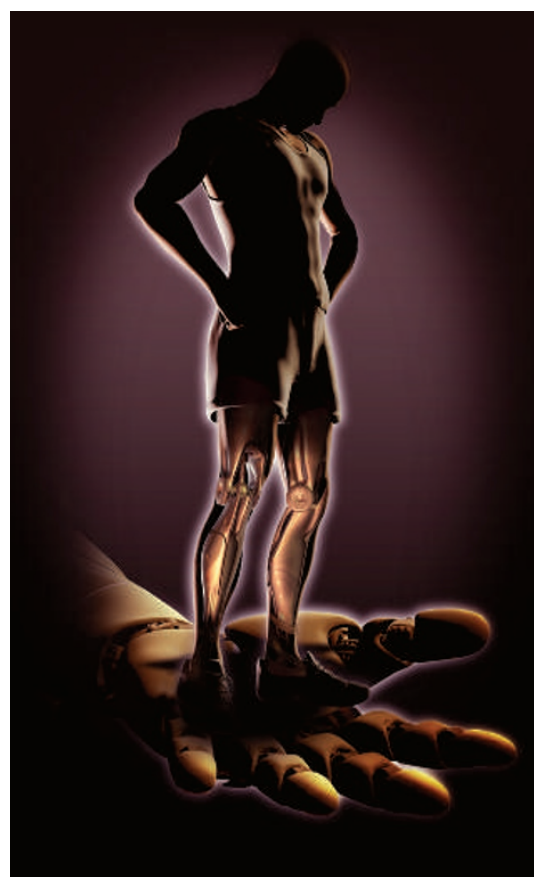

Hsui shook John's hand, replying softly, "My brother lost a hand in the war." He let go and turned to his starting blocks.

"Thank you," John said to his back.

John swept Hsui's fears, and his own, into a deep breath and puffed them out, relaxing his cheeks. He rocked a bit, setting his calves, running a quick mental skip across the sensors in his skin, checking the breeze, temperature and humidity. $\mathrm{He}$ struggled to close his ears as the announcer droned on. Kim's legs - his - wouldn't win by themselves. He mentally shrank the world to a bubble around him, and the long slender corridor of space on the track in front of him.

The starting gun swept him forward, following Hsui.

He fell in right behind, body straight, arms pumping.
No need to pass.

Yet.

He let the first round of the track go, calibrating, biding time. His legs were all he had, he'd refused changes to his lungs and circulatory system, wanting some purity. Important not to overrun his breath.

He was about to pass the fastest human ever. The fastest pure human. He threw the thought away. A break in stride or a stumble could steal the race. Counting and breathing and moving. Just the track under him and the narrow corridor, the wind on his teeth. Breath and wind and stride and arms.

His head turned a little, as if the force of Hsui's run called it. Hsui didn't return John's darting glance, just kept going, head up. Surging. To match him, John told his legs to give more, asked his heart to keep up.

Breath and wind and spine and floor. Data instead of Hsui's desperate face.

Another turn around the track, a matched pair.

The image of two feet crossing at the same time raced through John's head. An honourable outcome. Except he was a racer. The sound of Hsui's breath fell to behind John's shoulder. The finish line blurred under him.

Nic's arms encircled him. Kim leapt up on Nic's back. Nic grabbed her under the knees, boosting her like a child. She looked down, her joy at the win overtaken by a crease in her brow. "Why so slow?"

He shook his head, unsure how to explain it. "I'll be right back." Hsui jogged well past him now, sweat dripping down his back.

John caught him. "I hope your brother is proud of you."

Hsui winced. "He went back to the war. They put him in special ops 'cause his hand-eye coordination was so much better than anyone else's." He looked away. "After his enhancements his hand was steadier than anybody else's."

Hsui had lost face to honour a brother with no more change than a hand? A man who had done well for himself? Hsui continued. "He's dead. They gave him a purple heart." He turned, and without so much as a smile, the fastest man in the world walked away from the fastest un-man in the world.

Brenda Cooper is a futurist, a writer and the chief information officer for the City of Kirkland, Washington. Her latest novel is The Silver Ship and the Sea from Tor Books. 